\title{
Seed germination evaluation of Phalaenopsis amabilis in various media for long-term conservation
}

\author{
DWI MURTI PUSPITANINGTYAS, ELIZABETH HANDINI* \\ Center for Plant Conservation and Botanic Gardens (Bogor Botanic Gardens), National Research and Innovation Agency. Jl. Ir. H. Juanda No. 13, Bogor \\ 16122, West Java, Indonesia. Tel.: +62-251-8322187, Fax.: +62-251-8322187, `email: puspitakrb@yahoo.com \\ Manuscript received: 30 September 2021. Revision accepted: 31 October 2021.
}

\begin{abstract}
Puspitaningtyas DM, Handini E. 2021. Seed germination evaluation of Phalaenopsis amabilis in various media for long-term conservation. Biodiversitas 22: 5231-5238. Phalaenopsis amabilis (L.) Blume (moon orchid) is one of Indonesia's national flowers, which is mentioned in Presidential Decree No. 4/1993. Study on the orchid seed of P. amabilis was conducted to observe the longevity of seeds storage. The purpose of this study was to determine the viability of $P$. amabilis seeds after storage for years, then to predict the life span of the seeds, and to find out the best media germination for $P$. amabilis seeds. After harvesting, $P$. amabilis seeds were stored at $-20{ }^{\circ} \mathrm{C}$ and the germination tests were carried out periodically in different periods until the seeds lose their viability to de termine the optimum conditions for long-term seed storage. Four trial media cultures have been used to test seed germination by means of in vitro culture. The result showed that seeds of $P$. amabilis were able to germinate in 4 media i.e. Knudson C, modified Knudson C, modified Vacin \& Went and modified leaf fertilizer. The best germination was on leaf fertilizer medium. Based on the research showed that the viability seeds of $P$. amabilis decreased sharply after 6 years stored. By using regression analysis, the life span of the seeds could be predicted can reach 9 years of storage which is sowing on the best media (leaf fertilizer).
\end{abstract}

Keywords: Germination, life span, orchid, Phalaenopsis amabilis, seed storage

\section{INTRODUCTION}

Phalaenopsis is regarded as the most popular orchid genus in the horticultural industry due to its aesthetic value and flower durability. It has an economic value as both potted ornamental plants and cut flowers as well with long flowering periods. It also has diversity in terms of species and ecology. This orchid has a monopodial epiphytic form and is not branched (Balilashaki et al. 2014). Approximately there are 64 species of Phalaenopsis (Cribb dan Schuiteman 2012) and 21 to 25 of them are spread throughout Indonesia (Puspitaningtyas and Mursidawati 1999; Christenson 2001; Mahfut 2019). In 1993 Phalaenopsis amabilis (L.) Blume was officially designated as one of the national flowers of Indonesia through Presidential Decree No. 4 of 1993, as it is widespread throughout the Indonesian archipelago. It is one of the species which has been widely cultivated as an ornamental and has been used by breeders to produce many hybrids and cultivars. That is the reason for the high demand for orchid seeds as research material.

The existence of Phalaenopsis orchids is scattered in various Indonesian archipelagos, but now the existence of these orchids is starting to be threatened with extinction due to the decreasing number and diversity. So there needs to be a strategic step to keep the existence of this orchid sustainable and maintained through in situ and ex situ conservation efforts.

All orchids are listed on Appendix I or II of the Convention on International Trade in Endangered Species (CITES), which makes it an offense to trade this species between countries without a permit. P. amabilis has not been evaluated according to the recent IUCN Red List criteria. Most orchid species become endangered because of over-collection and loss of habitat, so there is an urgent need to develop techniques to conserve them both in situ as well as ex-situ (Rubluo et al. 1993). Orchid seeds have limited food storage reserves, which are necessary for germination and protocorm development, making seed germination under natural conditions relatively low $(<5 \%)$ (Zeng et al. 2015; Vudala and Ribas 2017). In addition, orchid seeds that may have low germination can become extinct quickly in nature due to unsupportive environments (Balilashaki et al. 2014). Due to climate change which is related to habitat extinction, cause food reserves in natural habitats might be no longer support species to survive (Seaton et al. 2010). Since orchid seeds are small and dustlike, they have no endosperm and require a mycorrhizal symbiosis for germination and development. However, in vitro propagation methods have offered rapid propagation for commercial species such as Phalaenopsis and conservation of wild orchids (Balilashaki et al. 2014).

Asymbiotic seed germination with the addition of organic supplements is an excellent technique for mass propagation and efficient acclimatization of orchids for reintroduction into natural habitats, which will facilitate the conservation of endangered orchid species. Orchid seeds can be germinated in vitro using simple nutrient media containing sugar because survival rates in wild habitats are very low. The availability of asymbiotic seed germination and clonal propagation in vitro has also made commercialscale orchid cultivation possible and created an 
economically feasible market. Asymbiotic germination represents an ideal system for studying the growth and development of orchid seeds and seedlings (Kauth et al. 2008), and many culture media have been successfully used for the germination of various species of orchids (Arditti and Ernst 1993), such as MS (Murashige and Skoog 1962), KC (Knudson 1946) and VW (Vacin and Went 1949).

Seed storage is also very important for plant breeding, which is an efficient way to conserve genetic resources and preserve rare or endangered germplasm. Orchid seeds differ from the majority of flowering plants by having minute embryos. A single fruit or capsule produces tens of thousands to millions of seeds (Arditti and Ghani 2000), and an effective way to seed bank a species (Swarts and Dixon 2009). The basic problem in conservation activities is seed storage and regeneration. Seeds from the Orchidaceae family, tolerate dry storage at $-20^{\circ} \mathrm{C}$. In addition, the small size of orchid seeds $(0.05-6 \mathrm{~mm})$ and weight $(0.31-24 \mu \mathrm{g})$, allow storage in a huge number of seeds in small volume jars.

Seed storage activities are cheaper than maintaining live collections (Neto and Custodio 2005). Storage of seeds in the short term (seed viability for 1-5 years stored) or longterm (resistant seeds stored for more than 5 years) has been recognized as the most efficient way of storing live plants in large quantities (Udomdee et al. 2014). Viability can be retained 5-20 years at refrigerator temperatures depending on the species being stored (Shoushtari et al. 1994).

Seeds of many orchid species are regarded as possessing orthodox storage behavior, as their longevity can be enhanced by reducing their moisture content and lowering storage temperatures, under the conditions commonly utilized in many seed banks (Pritchard and Seaton 1993; Pritchard et al. 1999; Seaton and Pritchard 2003; Seaton et al. 2010; Seaton et al. 2013; Merritt et al. 2014). Phalaenopsis seeds are orthodox in their storage behavior. Therefore, if Phalaenopsis seeds are to be stored, their harvest should be delayed until the moisture content drops below 50\% (Schwallier et al. 2011). However, there are few studies on the longevity of orchid seeds (Suzuki et al. 2012).

Currently, very few gene banks that preserve orchid germplasm as seeds and procedures to improve orchid seed storage for germplasm conservation are needed (Mweetwa et al. 2007). Thus, the seed bank is a major strategy for conserving valuable genetic resources and possibly reintroduction them into their natural habitat (Franceschi et al. 2019).

The objectives of this study were to determine the best medium for in vitro germination of $P$. amabilis. Furthermore, this study aimed to assess the germination test of seeds stored and to predict the life span of $P$. amabilis seeds when stored in a freezer at $-20^{\circ} \mathrm{C}$.

\section{MATERIALS AND METHODS}

\section{Sampling materials}

The study was conducted at the Laboratory of Tissue Culture Research Center for Conservation of Plants and Botanic Gardens, Bogor, Indonesia. Orchid seed materials of $P$. amabilis were obtained from orchid collections in Bogor Botanic Gardens Raya-LIPI. In order to obtain the orchid seed collection, the research was started by pollinating $P$. amabilis flowers. Flowers were handpollinated to ensure a good fruit set and seed quantity. Mature seeds of $P$. amabilis were harvested from browning seeds for about 5-6 months after pollination. Two pods of fruit were used as seed lots for germination tests, which contain thousands of seeds. After seeds harvesting, the research process begins with tested germination of fresh seeds and then continued with the drying seeds and storing them at $-20^{\circ} \mathrm{C}$.

\section{Drying seeds and storage}

After seeds were removed from the capsule, seeds were collected on Petri dishes and sieved to remove any remaining debris. According to the Orchid Seed Storage for Sustainable Use (OSSSU), seeds should be dried at low RH for a maximum of 7 days as recommended by Seaton et al. (2018). Seeds were dehydrated in a desiccator over silica gel for 5 days to reduce the moisture content of the seeds. Next, the dry seeds were rapidly transferred to small vials $(2 \mathrm{ml})$ with screw caps to avoid a change in seed moisture content. Seed vials were placed within larger tubes $(10 \mathrm{ml})$, together with a sachet of orange silica gel as an indicator inside to ensure that the jar remained airtight (not as a desiccant). Next, the individual small vials were all labeled with the species name and date of storage. Several seed vials were put together in a larger storage jar which was hermetically sealed. Storage was carried out in the freezer at $-20^{\circ} \mathrm{C}$ (Seaton and Ramsay 2005; Seaton et al. 2018). Then the germination tests were carried out periodically in different periods until the seeds lose their viability (Puspitaningtyas and Handini 2014; 2020).

\section{Seed sterilization and sowing seeds}

Phalaenopsis amabilis seeds were tested for germination following hermetic storage for up to eight years until the seeds lose their viability or when seed stock has run out. Asymbiotic seed germination began with seed sterilization before sowing on the seedling media. Sterilization was done by soaking the seeds sample in a sterile distilled water bottle to which 3 drops of Tween 80 had been added. Then the seeds in sterile distilled water were vacuumed for one hour. The next process was carried out in a laminar airflow hood. The tween 80 solution was removed with a pipette after the seeds had sunk to the bottom of the bottle. 
Next, the seeds were soaked in $10 \%$ Clorox solution for 10 minutes, followed by soaking in $5 \%$ Clorox solution for 5 minutes. The next step was to rinse with sterile distilled water up to three times. In the third rinse, seeds were sown onto the agar media. Then the sterile distilled water was sucked and removed so that only the seeds were left on the media. The petri dish media were then labeled with the name of the species and the medium as well as the planting date information. After that, the Petri dishes were covered with plastic wrap (Puspitaningtyas and Handini 2014; 2020).

\section{Media for asymbiotic seed germination}

Four different basal media such as KCA (pure Knudson $\mathrm{C}$ with the addition of microelements, that are $\mathrm{H} 3 \mathrm{BO} 3$ $0.056 \mathrm{mg} / \mathrm{L}, \mathrm{MoO} 30.016 \mathrm{mg} / \mathrm{L}, \mathrm{ZnSO} 40.331 \mathrm{mg} / \mathrm{L}$, and CuSO4 0.624 mg/L (Seaton and Ramsay 2005), KC (Knudson C modification with the addition of $1 \mathrm{~g} / \mathrm{l}$ of activated charcoal, extract of bean sprout $150 \mathrm{~g} / \mathrm{l}$ and coconut water $150 \mathrm{ml} / \mathrm{l}$, VW (Vacin and Went modification with the addition of active charcoal $1 \mathrm{~g} / \mathrm{l}$, extract of bean sprouts $100 \mathrm{~g} / \mathrm{l}$, extract of tomatoes $100 \mathrm{~g} / \mathrm{L}$ and coconut water $150 \mathrm{ml} / \mathrm{L}$ ), and HS (Hyponex leaf fertilizer with the addition of activated charcoal $1 \mathrm{~g} / \mathrm{L}$, peptone $2 \mathrm{~g} / \mathrm{L}$ and potatoes $40 \mathrm{~g} / \mathrm{L}$. All the media were supplemented with $3 \%$ (w/v) sugar and solidified with $0.8 \%$ (w/v) agar. The $\mathrm{pH}$ of the media was adjusted to 5.6-5.8 with $1 \mathrm{~N} \mathrm{NaOH}$ or $\mathrm{HCl}$ (Puspitaningtyas and Handini 2014; 2020).

\section{Data analysis}

Seed sampling is carried out periodically to calculate seed viability. Within a year of storage, the germination of stored seeds was tested regularly every 6 months. If the seed of $P$. amabilis still viable after being stored for one year, then germination tests were continued regularly every two years until the seeds lose their viability. A total of 100200 seeds are sown in each petri dish. Seeds that begin to germinate are observed and counted under a 40x magnification microscope. The rupture of the seed coat and the appearance of an enlarged embryo i.e. the protocorm was considered as germination. The seeds were classified as germinated or non germinated. The germination percentage was calculated by counting the total number of germinated seeds divided by the total number of seeds sown in one petri dish multiplied by $100 \%$. Each type of media was replicated up to three times (Puspitaningtyas and Handini 2014; 2020).

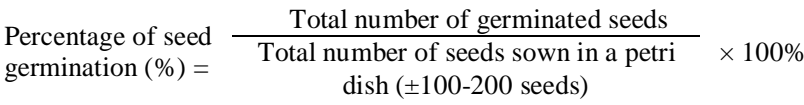
dish ( $\pm 100-200$ seeds $)$

The experimental units were set up in a completely randomized design (CRD) with one-factor media. Data were subjected to analysis of variance (ANOVA) using SAS variance analysis version 9.00 , and the mean values were separated using Duncan's Multiple Range Test (DMRT) with significance at the 5\% level. Prediction of seed longevity was calculated using regression conducted with Curve Expert 1.3 software on the mean of all seed media.

\section{RESULTS AND DISCUSSION}

\section{Harvested seeds of Phalaenopsis amabilis}

The mature $P$. amabilis seeds were harvested from ripe pods, which were characterized by cracked pods (Figure 1.B). Based on the observation, the fruit of $P$. amabilis was elliptically elongated like a capsule, measuring about 5-8 $\mathrm{cm}$ long, $\pm 1-1.5 \mathrm{~cm}$ in diameter, round fruit $2-3 \mathrm{~cm}$. The shape of the seeds was an elongated oval, measuring 0.3 $0.4 \mathrm{~mm}$ long and $\pm 0.1 \mathrm{~mm}$ wide and the seed color was brown (Figure 1.B). This observation was also supported by McKendrick et al. (2000) that the size of Phalaenopsis orchid seeds is about $0.4 \mathrm{~mm} \times 0.08 \mathrm{~mm}$. Referring to the length of the seeds, they can be classified as small ranging from 200-500 $\mu \mathrm{m}$ (Barthlott et al. 2014). Seeds contain a globular-shaped embryo and lack a well-defined endosperm (Arditti 1992; Yam et al. 2002). Embryos were located in the middle of the seed (Figure 1.C).
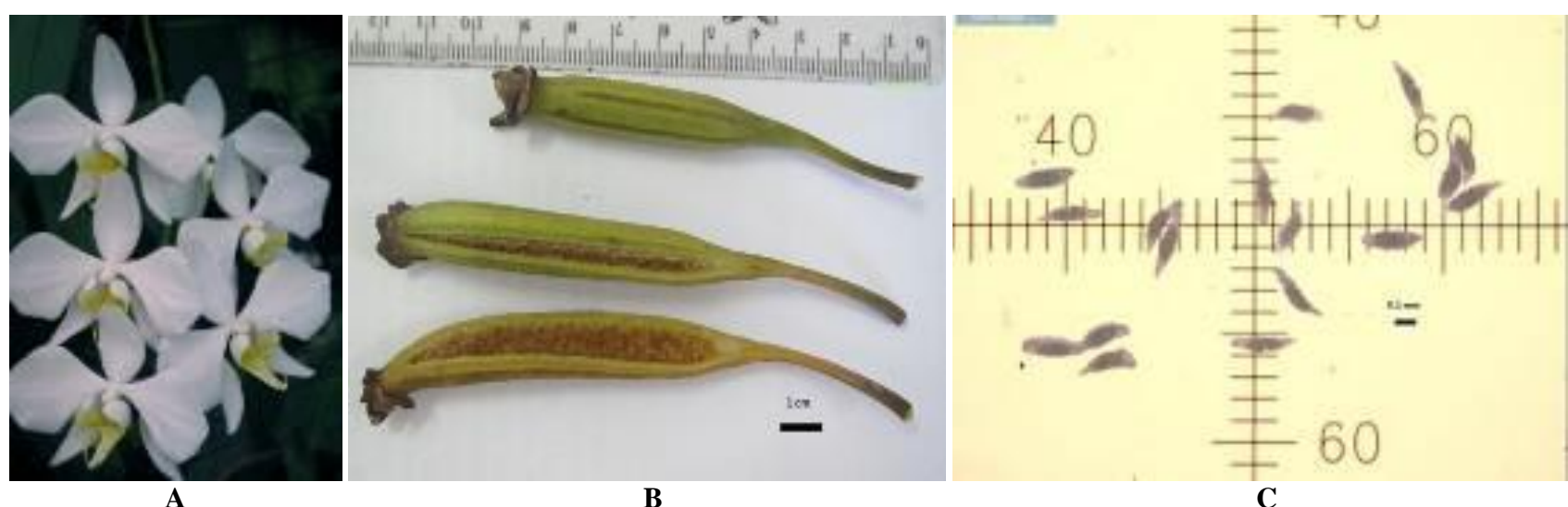

Figure 1. Flowers, fruit and orchid seeds of Phalaenopsis amabilis. A. Flowers, B. Fruit (Bar: $1 \mathrm{~cm})$, C. Seeds magnified 100× (Bar: 0.1 $\mathrm{mm})$ 
Ideally, the seed will have been harvested when mature, just as the seed capsule has begun to split or crack. The use of mature seeds is generally a preferable approach as they remain viable for long periods under refrigeration (Kitsaki et al. 2004). Although mature seeds have the advantage of remaining viable for long periods, they become dormant with maturation (Kitsaki et al. 2004). Mweetwa et al. (2007) demonstrated that dormancy was broken by lowtemperature treatments. In nature, orchid seeds may exhibit physiological (Rasmussen 1995) or morphophysiological (Whigham et al. 2006) dormancy. Dormancy can be broken by darkness, temperature, or atmospheric conditions. Mweetwa et al. (2008) stated that seeds of $P$. amabilis harvested from mature green seed pods 120 DAP (day after pollination) produced the best quality seed for propagation and the highest germination percentages. Those seeds were not be treated with sodium or calcium hypochlorite, because pods were harvested intact and seeds were not exposed to epiphytic bacteria and other potential contaminants. On the other hand, Schwallier et al. (2011) suggested that Phalaenopsis capsules were harvested after 165 DAP. Seed germination remained high (75-99.5\%) throughout the harvesting period (90-216 DAP), and desiccation tolerance only developed 165 days after pollination. The ripeness of the seeds was reached at the end of ripening capsules associated with decreased water content and was essential to success storage of the hybrid seeds of $P$. amabilis (Schwallier et al. 2011).

\section{Germination test on different media}

The results showed that seedlings of $P$. amabilis could germinate on the four media tested. The quality of fresh seeds $P$. amabilis was very good because the seeds had sown in four media germinated almost more than $95 \%$ in all media tested. The seeds started swollen into protocorm after one-week sowing, then within 3-4 weeks, some seeds develop into normal seedlings with rhizoid. It has been shown that media differences have a significant effect on the quality of growth and development of protocorms. The development of $P$. amabilis seeds into protocorms was better on modified Knudson C (KC) and Hyponex (HS) media for up to 12 months (1 year) storage, while other media (VW and KCA) showed a significantly lower percentage of germination for each time storage (Figure 2). However, the protocorms had better performance growing on $\mathrm{KC}$ and KCA media. They were green, had bigger sizes and more rhizoids (Figure 2).

According to Suzuki et al. (2012), sowing seeds on media with adequate nutrient composition helps to increase the germination rate, so that it can produce plants in large quantities. This contributes to the conservation of orchids, especially for endangered species. The addition of organic material gives a better response to the growth and development of protocorms. Organic additives such as coconut milk, bean sprouts, potatoes, banana pulp, peptone, and tomato extract promote the growth and development of seeds and regeneration of plantlets (Tawaro et al. 2008; Kaur and Bhutani 2012; Shekarriz et al. 2014; Utami and Hariyanto 2016).

Coconut water is commonly used in plant and orchid tissue cultures (Kyte and Kleyn 1996; Yong et al. 2009). The extensive use of coconut water as a growth-promoting component in the formulation of orchid tissue culture media has been reviewed by Utami and Haryanto (2020). The addition of coconut water in seed media as much as $10-30 \%$ can stimulate the protocorm growth of Cymbidium finlaysonianum Lindl. (Tawaro et al. 2008; Puspitaningtyas and Handini 2020). According to Shekarriz et al. (2014) that orchid medium should be supplemented with $2 \mathrm{~g} / \mathrm{L}$ peptone and $15 \%(\mathrm{v} / \mathrm{v})$ coconut water for optimal seed germination and Protocorm Like Bodies (PLBs) formation of Phalaenopsis hybrid 'Manchester'. It had proven that the supplementation of coconut water in both liquid and solid medium enhanced the survival of PLBs of Cattleya tonia (Uesato and Sagawa 1986) and enhanced the proliferation of PLBs of Vanda Kasem's Delight (Gnasekaran et al. 2012).

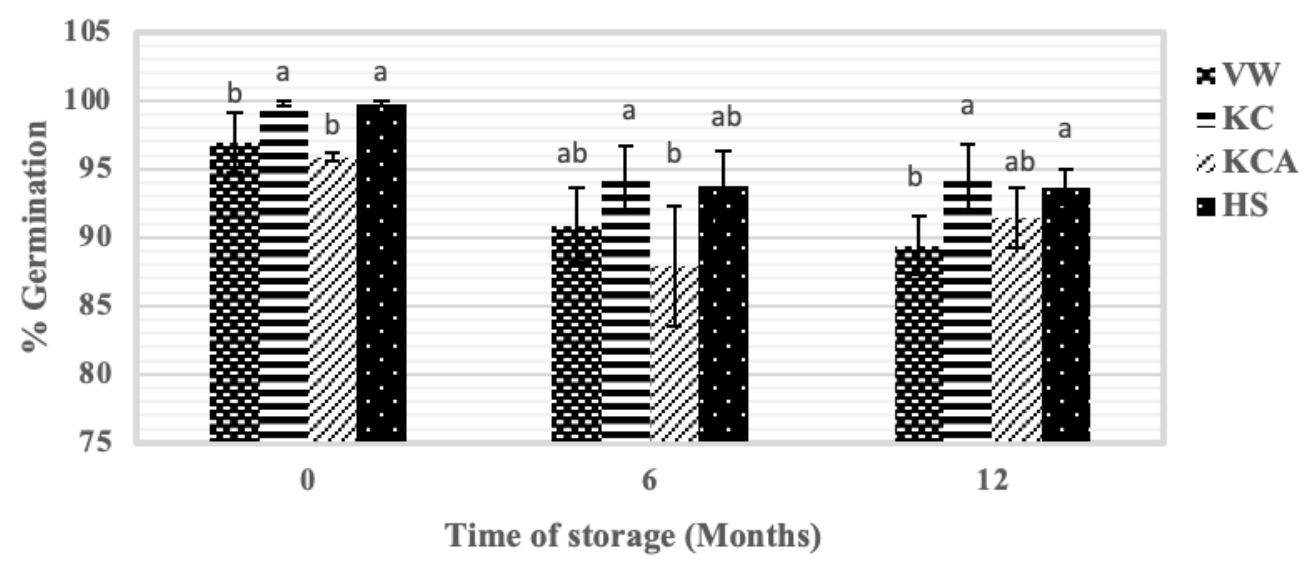

Figure 2. Seed germination of Phalaenopsis amabilis in different media for twelve months storage. VW: Vacin and Went; KC: Knudson C; KCA: pure Knudson C; HS: Hyponex leaf fertilizer. The mean \pm SD followed by different letters in the same storage time indicate significant difference according to Duncan's test at a significance level $\alpha=0.05$ 
Protocorm growth on $\mathrm{KC}$ modification is better than on pure Knudson $\mathrm{C}$ (KCA) which showed by the bigger size of protocorms and the number of rhizoids. The addition of organic matter coconut water and extract bean sprouts at the $\mathrm{KC}$ modification was able to increase the growth of protocorm. Coconut water is a more complex combination of compounds. Coconut water contains amino acids, organic acids, nucleic acids, several vitamins, sugar, and sugar alcohol, which fully improve the quality of plant growth (Yong et al. 2009; Molnár et al. 2011; Gnasekaran et al. 2012; Shekarriz et al. 2014). In addition, coconut water also contains the hormone auxin, various cytokinins, GAs (gibberellins acid) and ABA (abscisic acid), which enhance the growth of protocorm and seedling by inducing cell division (Ge et al. 2005; Vejsadova 2006; Yong et al. 2009).

The growth of $P$. amabilis protocorms on the media HS had relatively good performance although not as good as on $\mathrm{KC}$ and KCA media. Media HS contained the most simple element such as Nitrogen, Phosphor and Kalsium $(25: 5: 20)$ with the addition of organic materials. The addition of organic materials (peptone $2 \mathrm{~g} / \mathrm{L}$ and potatoes $40 \mathrm{~g} / \mathrm{L}$ ) might increase the growth of protocorms. This is in line with Vejsadova's opinion (2006) which stated that the addition of peptone could enhance the growth of shoots $43 \%$ better on seedling orchid Dactylorhiza maculata subsp. maculata. Moreover, peptone is an organic nitrogen source, may have contributed to the increased seedling development by supplying auxin-like compounds or various amino acids (Kauth et al. 2006). This is also consistent with the research of Shekarriz et al. (2014) that peptone supported the in vitro seed germination and number of PLBs (Protocorm Like Bodies) Phalaenopsis hybrid. Peptone was reported to have induced multiple shoots in Cymbidium macrorhizon and other Cymbidium species (Kusumoto and Furukuwa 1977) and also induced multiplication of protocorm-like bodies (PLBs) of Cymbidium pendulum (Kaur and Bhutani 2012). Furthermore, peptone was also reported to have induced multiple shoots in Paphiopedilum species and its hybrids (Hong et al. 2008; Ng and Saleh 2011; Kaur and Bhutani 2016). Moreover, peptone could also increase both the quality and quantity of protocorms' morphogenesis of Paraphalaenopsis serpentilingua (Puspitaningtyas and Dwiarum 2012). This is possible because peptone contains vitamins such as biotin, pyridoxine, thiamin, nitrogen (Dutra et al. 2008), amino acids, and proteins (Nhut et al. 2008) which are able to increase the growth and development of the explants. Moreover, peptone may play an important role in the activation of some genes related to the function of chlorophyll in the process of photosynthesis (Setiari et al. 2016).

However, differences in media affected the quality of growth and protocorm's color of $P$. amabilis. Visual observation on media of pure Knudson C (KCA) and Knudson $\mathrm{C}$ modification (KC) produces protocorms with dark green color, whereas on HS and VW modification media, the protocorms were rather pale yellowish brown (Figure 3). The protocorms color of $P$. amabilis on $\mathrm{KC}$ and KCA media were green graded from 141A to 142D, which was documented using the Royal Horticultural Society Colour Chart (RHSCC Edition V). However, the protocorms color of $P$. amabilis on $\mathrm{HS}$ and VW media were pale yellowish-brown graded from 147B to 147D (RHSCC Edition V). Furthermore, the protocorms look better grew on media $\mathrm{KC}$ and KCA than on media HS and VW. This was shown by the good performance of protocorms, which were green with plenty of rhizoids (Figure 3).

The green color of protocorms was due to the presence of chlorophyll. Chlorophyll synthesis is directly affected by the presence of iron $(\mathrm{Fe})$, magnesium $(\mathrm{Mg})$, and nitrogen (N), so that a deficiency of these elements can cause chlorosis (Ciompi et al. 1996; Laing et al. 2000). Fe is essential for chlorophyll synthesis and Fe participates in the electron transport in the process of reduction via cytochromes and ferredoxin (Marschner 1995; Mengel and Kirkby 2001). However, the HS media did not contain the element iron $(\mathrm{Fe})$ that is essential for chlorophyll synthesis. Meanwhile, in media VW, FeSO4.7H20 is chelated by Na2EDTA, so the absorption of element iron $(\mathrm{Fe})$ by protocorms is inhibited, and resulting in chlorosis explants that were pale green. Fe deficiency caused chlorosis due to decreased chlorophyll pigment content.

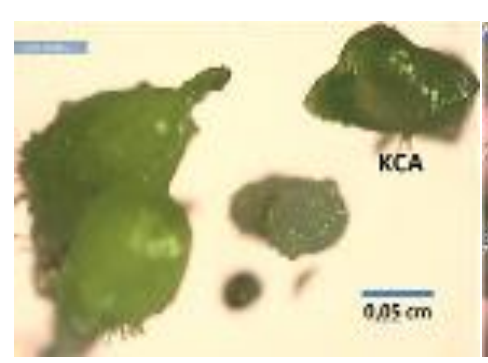

A

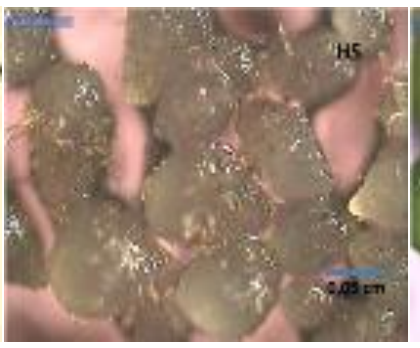

B

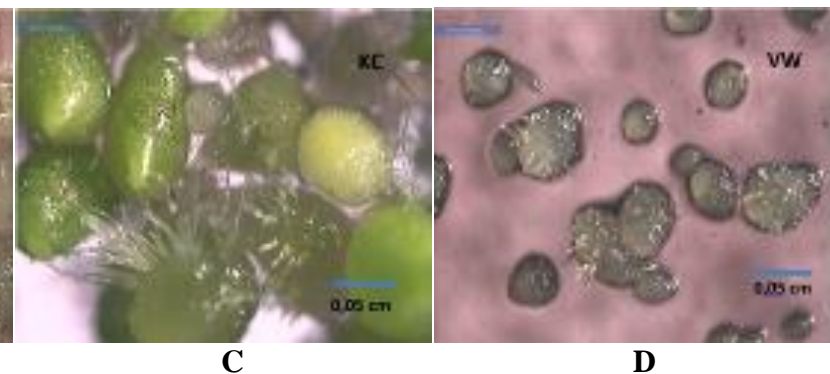

C
D

Figure 3. Seed germination of Phalaenopsis amabilis in four different media. A. Pure Knudson C (KCA), B. Hyponex leaf fertilizer (HS), C. Knudson C (KC), D. Vacin and Went $(\mathrm{VW}) .($ Bar $=0,05 \mathrm{~cm})$ 


\section{Germination test and orchid seed longevity of Phalaenopsis amabilis}

Assessing seed germination in orchids has been hindered by stringent germination requirements. It is known that orchid seed germination can be increasingly variable with storage time, perhaps reflecting seed provenance effects or changes in the optimum germination requirements.

Based on this study, the quality of $P$. amabilis seeds was very good as indicated by the initial high percentage of germination. The data showed that the percentage of fresh seed germination ( 0 years) was more than $95 \%$ in the four tested media (Figure 4). The seeds also gave a positive response to freezing temperature storage. This was shown by the germination percentage of two years stored seeds $P$. amabilis which was still high (above 80\%) in 3 media. However, in VW media the germination percentage was below $80 \%$ (Figure 4), within two years of storage at a freezing temperature of $-20^{\circ} \mathrm{C}$. This indicates that storage at low temperatures will prolong the viability of orchid seeds. Mweetwa et al. (2007) reported that some Phalaenopsis species seeds have a chilling requirement for germination. Based on the results of the study, the highest percentage of germination was obtained on HS media and the lowest percentage of germination was shown on VW media starting from the initial condition of fresh seeds $(0$ years) to eight years storage.

The results showed that storage of $P$. amabilis seeds at a freezing temperature of $-20^{\circ} \mathrm{C}$ could retain their viability up to $80 \%$ for two years storage, except on media VW that the seeds germination was less than $80 \%$. Then it was continued by germinating tests every two years. After four years of storage, seed viability decreased gradually to 39$57 \%$. Therefore, the time taken for seed viability to fall to $50 \%$ germination was around four years of storage. Then within six to eight years of storage, the viability of the seeds declined drastically to below $25 \%$, except on media HS (Figure 4). This is also supported by regression data analysis using Curve Expert 1.3 software to estimate seed longevity. Based on the analysis data, the viability test for eight years of storage showed negative linear regression (Figure 5). The viability of seed storage decreased rapidly as indicated by the declined percentage of germination. The longevity of $P$. amabilis seeds is estimated to be up to eight years storage at a freezing temperature of $-20^{\circ} \mathrm{C}$.

The seeds of $P$. amabilis exhibit orthodox behavior that tolerates desiccation and low temperatures during storage, which was indicated by high viability rates after storage for two years. Orthodox seeds are long-lived seeds and can be dried without damage to low moisture contents and are able to tolerate freezing. Although the seeds have presented this orthodox behavior, longer storage times should be tested for its maintenance in seed banks. Drying of orchid seed to an appropriate seed moisture content (MC) is key to maintaining its longevity. This equilibrium moisture content (eMC) will vary between species but is likely to be between 3 and 5\% (i.e. in equilibrium with 15-20\% RH) (Seaton et al. 2018). Drying orchid seeds can be done by storing the seeds in a desiccator over silica gel for 4-7 days (Greenspan 1977) or over saturated-solution (Calcium chloride/ $\mathrm{CaCl} 2$ or Lithium chloride/ $\mathrm{LiCl}$ ) and left for 3-4 days at room temperature for seed to equilibrate to the required moisture content (Seaton and Ramsay 2005).

It is proven that storing seeds at low temperature in a freezer $\left(-20^{\circ} \mathrm{C}\right)$ can prolong orchid seed viability of $P$. amabilis for up to eight years storage. Based on linear regression analysis, the seeds of $P$. amabilis can be predicted to be nearly completely non-viable within an average of 99,8 months ( 8.3 years) with an interval of 89.8-117.42 months (7.48-9.78 years) (Table 1$)$. The best medium for the germination test of $P$. amabilis seeds was Hyponex foliar fertilizer (HS). Calculation using linear regression formula, the longevity of $P$. amabilis seeds on HS media was predicted to be up to 10 years. Whereas on $\mathrm{KC}$ media was predicted up to 8.46 years, on KCA media was predicted up to 7.8 years and on VW media was predicted up to 7.4 respectively. This can be seen in Table 1 and it is shown in Figure 5.

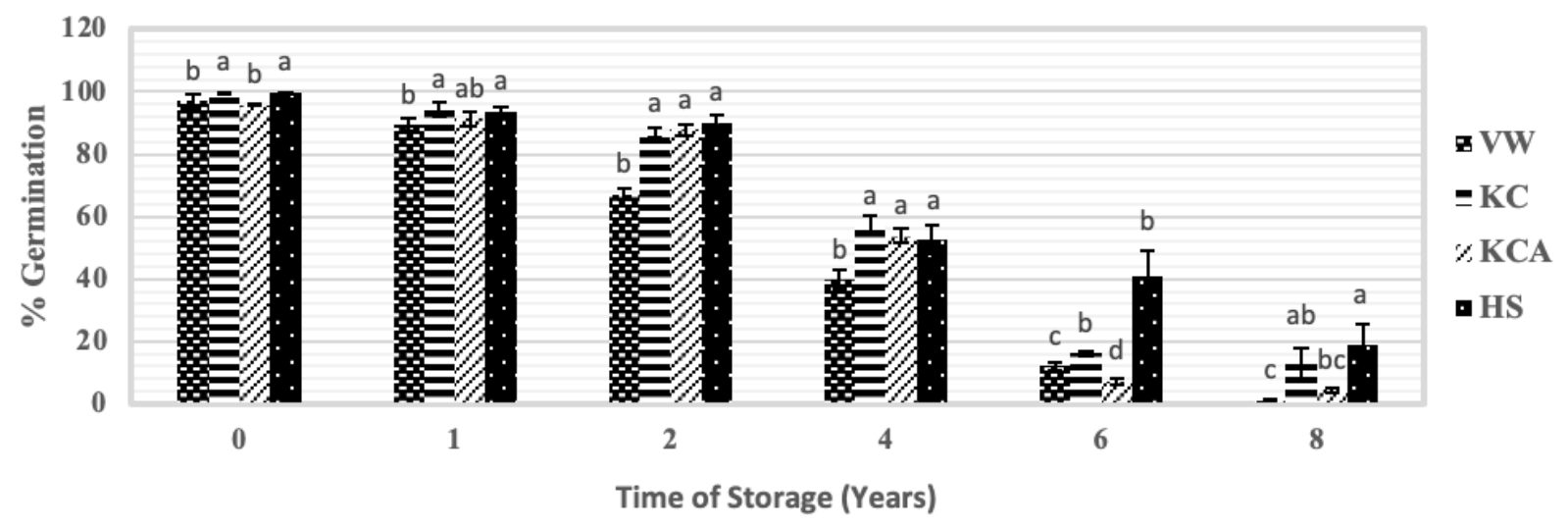

Figure 4. Seed germination of Phalaenopsis amabilis in different media for eight years storage. VW: Vacin and Went, KC: Knudson C, KCA: pure Knudson C, HS: Hyponex leaf fertilizer. The mean \pm SD followed by different letters in the same storage time indicate significant difference according to Duncan's test at a significance level $\alpha=0.05$ 
Table 1. Linear Regression of the life span of seed in storage for each media

\begin{tabular}{ll}
\multicolumn{1}{c}{ Media } & \multicolumn{1}{c}{ Life span prediction of stored seeds } \\
\hline KCA & $\mathrm{Y}=0, \mathrm{x}=93,8$ months or 7,8 years \\
KC & $\mathrm{Y}=0, \mathrm{x}=101,6$ months or 8.46 years \\
HS & $\mathrm{Y}=0, \mathrm{x}=117,42$ months or 9,78 years \\
VW & $\mathrm{Y}=0, \mathrm{x}=89.8$ months or 7,48 years \\
\hline
\end{tabular}

Notes: $\mathrm{Y}: 100.63-1.0083 \mathrm{x} ; \mathrm{Y}=0, \mathrm{x}=99,8$ months ( 8,3 years); Media: VW (Vacin and Went); KC (Knudson C); KCA (pure Knudson C); HS (Hyponex leaf fertilizer)

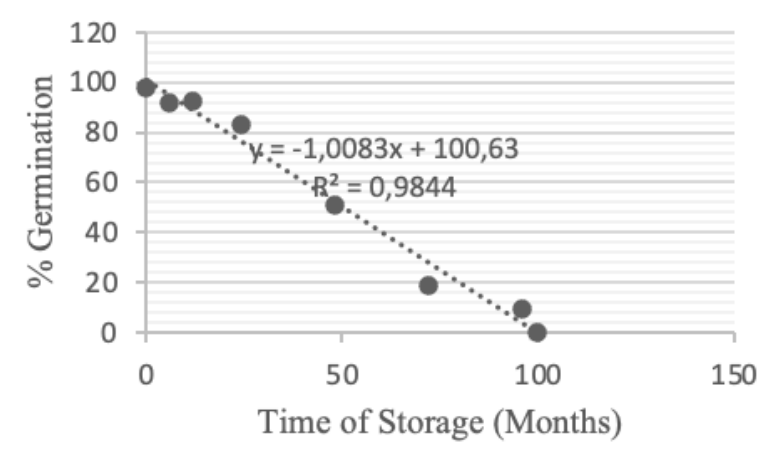

Figure 5. Linear regression of seed longevity of Phalaenopsis amabilis

Based on the present study, it may be concluded that seeds of $P$. amabilis were able to germinate in 4 media Knudson C (KCA), modified Knudson C (KC), modified Vacin \& Went (VW), and modified Hyponex fertilizer (HS). However, the media that produced the highest percentage of germination for $P$. amabilis was HS medium, but the best protocorm performance was on $\mathrm{KC}$ medium which was indicated by large protocorm development and the fastest rhizoid development.

Currently, seed storage plays an important role in the long-term conservation of plant genetic resources including orchids. In addition, asymbiotic germination provides an important tool for commercial propagation and conservation purposes. $P$. amabilis seeds have the potential for storage without loss of viability. The life span of $P$ amabilis seeds can be extended up to eight years with optimal viability of only two years, when the seeds are stored at a freezing temperature of $-20^{\circ} \mathrm{C}$ with low water content. However, after four years of storage, the seeds have lost their viability to fall to $50 \%$ germination. Low temperature $\left(-20^{\circ} \mathrm{C}\right)$ and dry moisture content is an appropriate simply method to preserve mature seeds of $P$. amabilis for long-term storage. Long-term seed storage is an important ex-situ conservation strategy for P. amabilis seeds.

\section{ACKNOWLEDGEMENTS}

This research is a part of the Orchid Seed Stores for Sustainable Use (OSSSU) project, which aims to store seeds representing at least 1000 orchid species in at least 30 countries in 2016. The author offers sincere thanks to Hugh W. Pritchard, Philip Seaton, and Tim Marks as the management team of the Orchid Seed Stores for Sustainable Use (OSSSU) project, who have funded this research project activity start in 2007 to 2010 . DMP is the main author, designed the project, carried out the experiments, and wrote the manuscript with the support of EH. EH is co-authors, carried out the experiments, processed the experimental data, and performed the statistical analysis.

\section{REFERENCES}

Arditti J. 1992. Fundamentals of Orchid Biology. John Wiley and Sons, Inc., New York.

Arditti J, Ernst R. 1993. Micropropagation of Orchids. A WilleyInterscience Publication, Canada.

Arditti J, Ghani AKA. 2000. Tansley Review No. 110: Numerical and physical properties of orchid seeds and their biological implications. New Phytol 145: 367-421.

Balilashaki KH, Naderi R. Kalantari S, Vahedi M. 2014. Efficient in vitro culture protocols for propagating Phalaenopsis 'Cool Breeze'. Plant Tissue Cult Biotechnol 24 (2): 191-203.

Barthlott W, Große-Veldmann B, Korotkova N. 2014. Orchid seed diversity: A scanning electron microscopy survey. In: Nicholas J. Turland (ed.). Botanic Garden and Botanical Museum Berlin-Dahlem.

Christenson EA. 2001. Phalaenopsis: A monograph. Timber Press, Oregon.

Ciompi S, Gentili E, Guidi L, Soldatini GF. 1996. The effect of nitrogen deficiency on leaf gas exchange and chlorophyll fluorescence parameters in sunflower. Plant Sci 118: 177-184. DOI: 10.1016/01689452(96)04442-1.

Cribb PJ, Schuiteman A. 2012. Phalaenopsis: Classification. Renziana 2: 14-40.

Dutra D, Johnson TR, Kauth PJ, Stewart SL, Kane ME, Richardson L. 2008. Asymbiotic seed germination, in vitro seedling development, and greenhouse acclimatization of the threatened terrestrial orchid Bletia purpurea. Plant Cell Tiss Organ Cult 94: 11-21. DOI: 10.1007/s11240-008-9382-0.

Franceschi CRB, Smidt EC, Vieira LN, Ribas LLF. 2019. Storage and in vitro germination of orchids (Orchidaceae) seeds from Atlantic Forest-Brazil. Anais da Academia Brasileira de Ciências 91 (3): 2-11. DOI: 10.1590/0001-3765201920180439.

Ge L, Yong JWH, Goh NK, Chia LS, Tan SN, Ong ES. 2005. Identification of kinetin and kinetin riboside in coconut (Cocos nucifera L.) water using a combined approach of liquid chromatography-tandem mass spectrometry, high-performance liquid chromatography and capillary electrophoresis. J Chromatogr B 829: 26-34. DOI: 10.1016/j.jchromb.2005.09.026.

Gnasekaran P, Poobathy R, Mahmood M, Samian MR, Subramaniam S. 2012. Effects of complex organic additives on improving the growth of PLBs of Vanda Kasem's Delight. Australian J Crop Sci 12451248

Greenspan L. 1977. Humidity fixed points of binary saturated aqueous solutions. J Res Natl Bureau Stand 81A: 89-96. DOI: 10.6028/jres.081A.011.

Hong PI, Chen JT, Chang WC. 2008. Plant regeneration via protocormlike body formation and shoot multiplication from seed-derived callus of maudice type slipper orchid. Acta Physiol Plant 30: 755-759. DOI: 10.1007/s11738-008-0158-2.

Kaur S, Bhutani KK. 2012. Organic growth supplement stimulants for in vitro multiplication of Cymbidium pendulum (Roxb.) Sw. Hortic Sci 39: 47-52. DOI: 10.17221/52/2011-HORTSCI.

Kaur S, Bhutani KK. 2016. Asymbiotic seed germination and multiplication of an endangered orchid - Paphiopedilum venustum (Wall. ex Sims.) Pfitz. Acta Soc Bot Pol 85 (2): 3494. DOI: 10.5586/asbp.3494.

Kauth PJ, Vendrame WA, Kane ME. 2006. In vitro seed culture and seedlings development of Calopogon tuberosus. Plant Cell Tiss Organ Cult 85: 91-102. DOI: 10.1007/s11240-005-9055-1.

Kauth PJ, Dutra D, Johnson TR, Stewart SL, Kane ME, Vendrame W. 2008. Techniques and applications of in vitro orchid seed germination. In: 
Teixeira da Silva JA. Floriculture, Ornamental and Plant Biotechnology: Advances and Topics Issues. Global Science Books, Ltd., UK.

Kitsaki CK, Zygouraki S, Ziobora M, Kintzios S. 2004. In vitro germination, protocorm formation and plantlet development of mature versus immature seeds from several Ophrys species (Orchidaceae). Plant Cell Rep 23: 284-290. DOI: 10.1007/s00299-004-0841-8.

Knudson L. 1946. A new nutrient solution for the germination of orchid seed. Amer Orch Soc Bull 14: 214-217.

Kusumoto M, Furukuwa J. 1977. Effect of organic matter on growth of Cymbidium protocorms cultured in vitro. J Japan Soc Hortic Sci 45: 421-426. DOI: $10.2503 /$ jjshs.45.421.

Kyte L, Kleyn J. 1996. Plants from Test Tubes. An Introduction to Micropropagation. Timber Press, Portland, Oregon.

Laing W, Greer D, Sun O, Beets P, Lowe A, Payn T. 2000. Physiological impacts of $\mathrm{Mg}$ deficiency in Pinus radiata: Growth and photosynthesis. New Phytol 146: 47-57. DOI: 10.1046/j.1469-8137.2000.00616.x.

Mahfut. 2019. The Orchid of Phalaenopsis and Plant Virus Diseases. Aura CV. Anugrah Utama Raharja, Bandar Lampung. [Indonesian]

Marschner H. 1995. Mineral Nutrition of Higher Plants. Academic Press, London.

McKendrick SL, Leake JR, Taylor DL, Read DJ. 2000. Symbiotic germination and development of myco-heterotrophic plants in nature: Ontogeny of Corallorhiza trifida and characterization of its mycorrhizal fungi. New Phytol145: 523-537. DOI: 10.1046/j.14698137.2000.00603.x.

Mengel K, Kirkby E. 2001. Principles of Plant Nutrition 5th Ed. Kluwer Academic Publishers, London.

Merritt DJ, Hay FR, Swarts ND, Sommerville KD, Dixon KW. 2014. Exsitu conservation and cryopreservation of orchid germplasm. Intl J Plant Sci 175: 46-58.

Molnár Z, Virág E, Ördög V. 2011. Natural substances in tissue culture media of higher plants. Acta Biologica Szegediensis 55: 123-127.

Murashige T, Skoog F. 1962. Tissue culture - a new means of clonal propagation of orchids. Amer. Orch Soc Bull 33: 473-478.

Mweetwa AM, Welbaum GE, Tay D. 2007. Orchid seed storage for germplasm preservation. Acta Hortic 760: 629-635. DOI: 10.17660/ActaHortic.2007.760.89

Mweetwa AM, Welbaum GE, Tay D. 2008. Effects of development, temperature, and calcium hypochlorite treatment on in vitro germinability of Phalaenopsis seeds. Scientia Horticulturae 117: 257 262. DOI: 10.1016/j.scienta.2008.03.035.

Neto NBA, Custodio CC. 2005. Orchid conservation through seed banking: ins and outs. Selbyana 26: 229-235.

$\mathrm{Ng} \mathrm{CH}$, Saleh NM. 2011. In vitro propagation of Paphiopedilum orchid through formation of protocorm-like bodies. Plant Cell Tiss Organ Cult 105: 193-202. DOI: 10.1007/s11240-010-9851-0.

Nhut DT, Thi NN, Khiet BLT, Luan VQ. 2008. Peptone stimulates in vitro shoot and root regeneration of Avocado (Persea americana Mill). Scientia Horticulturae 115 (2): 124-128. DOI 10.1016/j.scienta.2007.08.011

Pritchard HW, Seaton PT. 1993. Orchid seed storage: Historical perspective, current status, and future prospects for long-term conservation. Selbiyana 14: 89-104.

Pritchard HW, Poynter ALC, Seaton PT. 1999. Interspecific variation in orchid seed longevity in relation to ultra-dry storage and cryopreservation. Lindleyana 14: 92-101.

Puspitaningtyas DM, Mursidawati S. 1999. Orchid collections of Bogor Botanic Gardens. Technical Implementation Unit of Botanic Gardens Development Center - Indonesian Institute of Sciences.

Puspitaningtyas DM, Dwiarum AC. 2012. Orchid conservation of Paraphalaenopsis serpentilingua by in vitro culture. Intl Conf Biol Sci, Gadjah Mada University, Yogyakarta.

Puspitaningtyas DM, Handini E. 2014. Orchid seeds storage of Coelogyne spp. for ex situ conservation. Buletin Kebun Raya 17 (2): 101-112. DOI: 10.14203/bkr.v17i2.142. [Indonesian]

Puspitaningtyas DM, Handini E. 2020. Ex-situ conservation of Cymbidium finlaysonianum by seed storage. Biodiversitas 21 (8): 3519-3524. DOI: 10.13057/biodiv/d210813.

Rasmussen HN. 1995. Terrestrial Orchids from Seed to Mycotrophic Plants. Cambridge University Press, Cambridge.

Royal Horticultural Society Colour Charts Edition V. 2021. http://rhscf.orgfree.com [8 June 2021].

Rubluo A, Chavez V, Martinez AP, Martinez-Vazques O. 1993. Strategies for the recovery of endangered orchids and cacti through in-vitro culture. Biol Conserv 63: 163-169.
Schwallier R, Bhoopalan V, Blackman S. 2011. The influence of seed maturation on desiccation tolerance in Phalaenopsis amabilis hybrids. Scientia Horticulturae 128: 136-140. DOI: 10.1016/j.scienta.2010.12.019.

Seaton PT, Pritchard HW. 2003. Orchid germplasm collection, storage and exchange. In: Dixon KW, Kell SP, Barrett RL, Cribb PJ. (Eds.). Orchid Conservation. Natural History Publications (Borneo), Sabah.

Seaton P, Ramsay M. 2005. Growing Orchids from Seed. Royal Botanic Garden, Sydney.

Seaton, PT, Hu H, Perner H, Pritchard HW. 2010. Ex-situ conservation of orchids in a warming world. Bot Rev 76: 193-203. DOI: 10.1007/s12229-010-9048-6.

Seaton PT, Seaton P, Kendon JP, Pritchard HW, Puspitaningtyas DM, Marks TR. 2013. Orchid conservation: The next ten years. Lankesteriana 13: 93-101. DOI: 10.15517/lank.v0i0.11545.

Seaton PT, Hosomi ST, Custódio CC, Marks TR, Machado-Neto NB, Pritchard HW. 2018. Orchid Seed and Pollen: A Toolkit for LongTerm Storage, Viability Assessment and Conservation. In: Lee Y-I, Yeung EC-T (eds.). Chapter 4: Orchid Propagation: from Laboratories to Greenhouses-Methods and Protocols. Springer Protocols Handbooks. DOI: 10.1007/978-1-4939-7771-0_4.

Setiari N, Purwantoro A, Moeljopawiro S, Semiarti E. 2016. Peptone and tomato extract induced early stage of embryo development of Dendrobium Phalaenopsis orchid. J Trop Biodiver Biotechnol 1 (2): 77-84. DOI: $10.22146 /$ jtbb.15498

Shekarriz P, Kafi M, Deilamy SD, Mirmasoumi M. 2014. Coconut water and peptone improve seed germination and protocorm-like body formation of hybrid Phalaenopsis. Agric Sci Dev 3 (10): 317-322.

Shoushtari BD, Heydari R, Johnson GL, Arditti J. 1994. Germination and viability staining of orchid seeds following prolonged storage. Lindleyana 9: 77-84.

Suzuki RM, Moreira VC, Pescador R, Ferreira WM. 2012. Asymbiotic seed germination and in vitro seedling development of the threatened orchid Hoffmannseggella cinnabarina. In vitro Cell Dev Biol Plant 48: 500-511. DOI: 10.1007/s11627-012-9460-1.

Swarts ND, Dixon KW. 2009. Terrestrial orchid conservation in the age of extinction. Ann Bot 104: 543-556. DOI: 10.1093/aob/mcp025.

Tawaro S, Suraninpong P, Chanprame S. 2008. Germination and regeneration of Cymbidium finlaysonianum Lindl. on a medium supplemented with some organic sources. Walailak J Sci Technol 5 (2): $125-135$

Udomdee W, Wen P, Chin S, Chen F. 2014. Effect of storage temperature on seed viability and in vitro germination of nobile Dendrobium hybrids. Thai Agric Res J 32 (2): 201-217.

Uesato K, Sagawa Y. 1986. Effects of sucrose and coconut water on the survival of PLB tissues of Cattleya tonia under cold storage. Sci Bull. Coll Agric Univ Ryukyus 33: 71-77.

Utami ESW, Hariyanto S. 2016. The effect of organic nutrient and growth regulators on seed germination, embryo, and shoots development of Dendrobium antennatum by in vitro. Biosaintifika 8 (2): 165-171. DOI: 10.15294/biosaintifika.v8i2.5165.

Utami ESW, Hariyanto S. 2020. Organic compounds: Contents and their role in improving seed germination and protocorm development in orchids. Intl J Agronom 2020: 2795108. DOI: 10.1155/2020/2795108.

Vacin EF, Went FW. 1949. Some $\mathrm{pH}$ changes in nutrient solutions. Botanical Gazette 110: 605-613.

Vejsadova H. 2006. Factors affecting seed germination and seedling growth of terrestrial orchids cultured in vitro. Acta Biologica Cracoviensia Series Botanica 48 (1): 109-113.

Vudala SM, Ribas LLF. 2017. Seed storage and asymbiotic germination of Hadrolaelia grandis (Orchidaceae). South Afr J Bot 108: 1-7. DOI: 10.1016/j.sajb.2016.09.008.

Whigham DF, O'Neill JP, Rasmussen HN, Caldwell BA, McCormick MK. 2006. Seed longevity in terrestrial orchids potential for persistent in situ seed banks. Biol Conserv 129: 24-30. DOI: 10.1016/j.biocon.2005.10.029.

Yam TW, Yeung EC, Ye XL, Zee SY, Arditti J. 2002. Orchid embryos. In: Kull T, Arditti J. (eds.). Orchid Biology: Reviews and Perspectives, VIII. Kluwer Academic Publisher, Dordrecht.

Yong JW, Ge L, Ng YF, Tan SN. 2009. The chemical composition and biological properties of coconut (Cocos nucifera $\mathrm{L}$.) water. Molecules 14 (12): 5144-5164. DOI: 10.3390/molecules14125144.

Zeng S, Huang W, Wu K, Zhang J, Teixeira da Silva JA, Duan J. 2015. In vitro propagation of Paphiopedilum orchids. Critical Rev Biotechnol 36 (3): 521-534. DOI: 10.3109/07388551.2014.993585. 